\title{
A Bibliometric Study of Informing Science: The International Journal of an Emerging Transdiscipline
}

\author{
Amanda Regolini and Emmanuelle Jannès-Ober \\ Irstea, DP2VIST, Antony, France
}

amanda.regolini@irstea.fr emmanuelle.jannes-ober@irstea.fr

\begin{abstract}
Informing Science is a young transdisciplinary science. the essential characteristics of which were defined fifteen years ago.

The journal Informing Science: the International Journal of an Emerging Transdiscipline (InformSciJ) is the flagship journal of transdisciplinary Informing Science. A study about the publication's influence and readership could be pertinent to better understanding the present state of Informing Science. To this end, we have performed a bibliometric study of first generation citations from InformSciJ. Publication data from Scopus were used. A bibliometric analysis based on citations to its papers may give clear indicators about the influence of this journal among institutions, countries, and researchers. This study also provides an overview of knowledge dissemination in various disciplines. Moreover, a citations study may be a barometer of the evolution of a transdiscipline.
\end{abstract}

The study demonstrates the high degree of transdisciplinarity of Informing Science. It is also confirmed that after more than a decade the Informing Science Institute continues to bring together researchers working in IS from many disciplines and nations.

The study confirms that it is possible to observe the evolution of a new transdiscipline by analysing the citations to papers from its flagship journal.

Keywords: Bibliometric analysis, transdisciplinarity, citation analysis, Informing Science.

\section{Introduction}

The fields of Informing Science (IS) were defined in 1999, by Eli Cohen in his seminal article as "The fields that comprise the discipline of Informing Science provide their clientele with information in a form, format, and schedule that maximizes its effectiveness" (Cohen, 1999).

In a decade this discipline has contributed greatly to bring together researchers working in IS

Material published as part of this publication, either on-line or in print, is copyrighted by the Informing Science Institute. Permission to make digital or paper copy of part or all of these works for personal or classroom use is granted without fee provided that the copies are not made or distributed for profit or commercial advantage AND that copies 1) bear this notice in full and 2) give the full citation on the first page. It is permissible to abstract these works so long as credit is given. To copy in all other cases or to republish or to post on a server or to redistribute to lists requires specific permission and payment of a fee. Contact Publisher@InformingScience.org to request redistribution permission. from many disciplines, including Management Information System (MIS), education, library science, and computer science (Gill \& Bhattacherjee, 2007).

The publishing activity of the Informing Science Institute (ISI) has been increasing enormously since the first issue of Informing Science: the International Journal of an Emerging Transdiscipline (InformSciJ) in 1997. ISI has under- 
taken the publication of seven additional journals and more of twenty books. Two annual international conferences are also managed by ISI (Gill \& Cohen, 2009).

InformSciJ has the mission to be the principal channel for sharing knowledge in the fields that comprise the discipline of Informing Science (Gill, 2009).

The term transdiscipline in InformSciJ's title is a relatively new term according to Choi and Pak's (2006). The authors found the first definitions of "transdiscipline" in on line literature published in 1979 (Gossman, 1979) and in peer-reviewed publications published in 1992 (Rosenfield, 1992). The Charter of Transdisciplinarity was adopted at First World Congress of Trandisciplinarity, Convento da Arrábida, Portugal, November 2-6, 1994.("Charter of transdisciplinarity," 1994)

What is a transdiscipline? Terms like multidisciplinary, interdisciplinarity, and transdisciplinarity describe activities that involve multiple disciplines. Let's get a closer look to some definitions by first taking some examples from health and social sciences:

- Multidisciplinary : Working with several disciplines

- Interdisciplinary : Working between several disciplines

- Transdisciplinary: Working across and beyond several disciplines. Members from different disciplines working together using a shared conceptual framework (Rosenfield, 1992). This usage of the term was introduced by Jean Piaget in 1970. (Nicolescu, 2002)

In others words, transdisciplinarity is a specific form of interdisciplinarity in which boundaries between and beyond disciplines are transcended and knowledge and perspectives from different scientific disciplines, as well as non-scientific sources, are integrated (Flinterman, TeclemariamMesbah, Broerse, \& Bunders, 2001)

The authors that have published in ISI publications come from a wide and varied multidisciplinary community. Having such publications allows information to reach a large number of consumers such as academic researchers (Cohen, 2009; Murphy, 2011). Those consumers, academic researchers, use ISI journals articles and cite them in different disciplines. The aim of this study is to observe the evolution of the Informing Science transdiscipline by analyzing the citations to papers from its flagship journal.

Our study is based on bibliometric citation analysis. The term bibliometric refers to a branch of library and information science that provides quantitative characterization of scientific activity. The technique used in this paper is known as citation analysis that is based on the postulate that scientist cite documents they consider to be important to their research (Garfield, 1955, 1997). A "citation" is quantifiable item in bibliometrics. This unit of analysis is the referencing of a document by a more recently published document. The document making the citation is the "citing" document, and the one receiving the citation is the "cited" document. (Börner, Chen, \& Boyack, 2003).

The methodological approach to characterize interdisciplinary research using citation analysis has been a research method for the last decades (Chubin, Porter, \& Rossini, 1984). Others methods based on web search data are being developed (Sayama \& Akaishi, 2012) but data gathering needs a great deal of cleaning work. The data is less structured and noisier than data collected from commercial citation indexing services such as Thomson Reuters's Web of Science (WoS) or Elsevier's Scopus. (Glänzel, 2012).

Google Scholar is another source that is used for citation analysis. Google Scholar, a service provided by Google, enables searches for scholarly publications. However, it does not meet all requirements of bibliometric study: proper documentation about coverage is missing (Yang \& 
Meho, 2006), a lot of changes of sources and citations happen within in short time periods. Therefore, reproducibility of search results is limited (Glänzel, 2012; Jasco, 2009). One of the major disadvantages of using this resource, due to the way the items are retrieved, is that there is often a large, and sometimes ambiguous, set returned. This can lead to very tedious data cleaning in order to gather the relevant data so as not to present obscure results (Meho \& Yang, 2007). For this reason Google Scholar was not considered for this study.

"Publish or Perish" (PoP) is a downloadable software developed by Prof. Anne-Wil Harzing of Melbourne University (Harzing, 2007). PoP provides an evaluation method for journals. This can be executed by pulling into a set all the articles published in them over a period of time and then calculating the h-index for the journal title (Gazni, Sugimoto, \& Didegah, 2012). This tool was discarded for the present study for two reasons: first, it is not possible to pull in a set the "citing articles"; second, this service uses Google Scholar to obtain citations.

A new tool "CleanPoP" is being developed. In the future, to calculate metrics one interesting way will be to search Google Scholar with PoP and then to clean results using CleanPoP (Baneyx, 2008).

Already, an analysis of authors, institutions, and countries of origin from Informing Science Institute (ISI) papers published between 1998 and 2009 was done in 2011 (Murphy, 2011). In his work, the study objects were all ISI papers published between 1998 and 2009. Murphy showed that $65 \%$ of ISI journal articles were written by authors affiliated with universities outside United States. He also analyzed the question of multidisciplinarity and concluded that ISI achieves relevance by publishing articles that examine questions related to informing.

In this paper the study object is the scholarly citations to InformSciJ. A bibliometric analysis based on citations to its papers could be fruitful as it can give clear indicators about the influence of the journal among institutions, countries, researchers, and subject areas. We focus the flagship journal of transdisciplinary Informing Science readership as sample to explore IS evolution.

\section{Data Gathering and Methodology Stages}

InformSciJ is indexed in several directories and data sets such as the Cabell's Directory of Publishing Opportunities in Educational Technology \& Library Science, Information Science Abstracts, Ulrich Web Global Serials Directory, and Scopus from Elsevier. Scopus allows users to conduct a citation analysis. To achieve the objective of this study, the data set was extracted from Elsevier's Scopus.

Scopus is a multidisciplinary bibliographic database of peer-reviewed research literature. It has been provided by Elsevier since 2004. Scopus is designed for bibliometric use. It covers more than 19,500 titles (including 1,800 Open Access journals) from more than 5,000 international publishers in the scientific, technical, medical, social sciences fields and arts and humanities (Osareh, 1996).

Scopus has a good coverage, but information is not indexed cover to cover. In fact, not all articles from InformSciJ are indexed. For example during 2012 only 3 articles out of 12 could be extracted. 


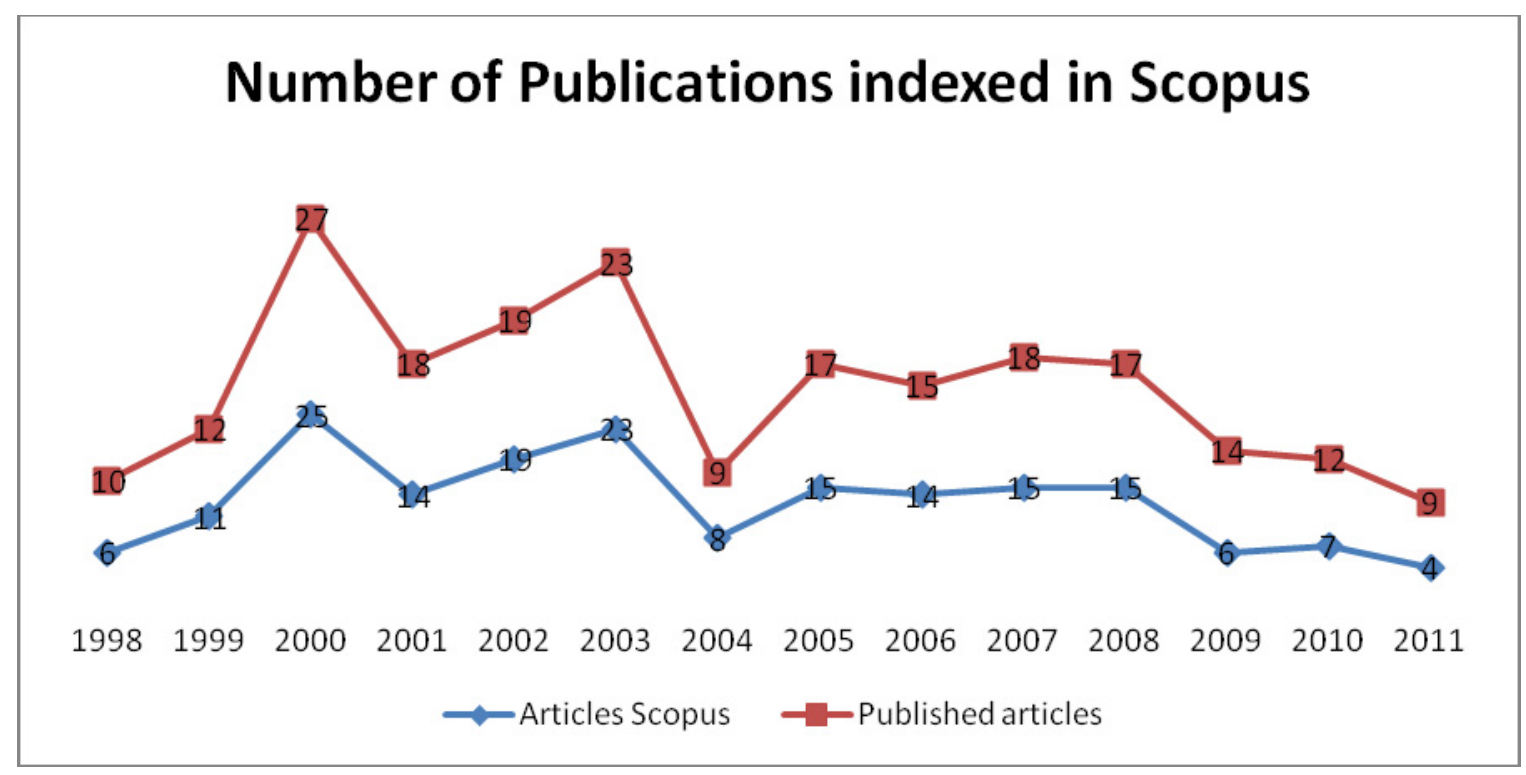

Figure 1: Number of indexed publications compared to number of InformSciJ published articles

184 InformSciJ articles are indexed in Scopus between 1997 and 2012 (extracted data on October 2012). If we compare that with the number of published articles of 229 , the rate of indexed papers is 0,80 . This rate must be taken into account when considering the results of the current analysis. In fact, it is important to bear in mind that for any bibliometric analysis, indicators are given for a specific period and for a specific set of publications extracted from a data base that as a rule indexes selectively within the journal and from selected journals, not from the universe of all possible journals.

In this work, the "citing" documents to InformSciJ's papers (cited) are studied. For each InformSciJ paper we retrieved the set of "citing" documents, also referred to as "first generation citations". The total number of retrieved citing publications (or first generation citations) was 857 . Thus, the set was cited 963 times. This is to say that in Scopus database there are 857 articles from different sources that cite in their bibliography one or more articles from InformSciJ.

The study stages of these 857 references are shown in Figure 2. The data set was processed with Sphinx ${ }^{\circledR}$ and VantagePoint ${ }^{\circledR}$, two lexical analyzer software programs. First, a citation analysis to compute the frequency of citations to InformSciJ articles was done in order to calculate the impact force. Second, we identified the relationship between different countries by using VantagePoint. This program allowed us to build-up countries co-occurrence. The Aduna ${ }^{\circledR}$ script cluster map will show the visualization of the most frequent collaborations. 


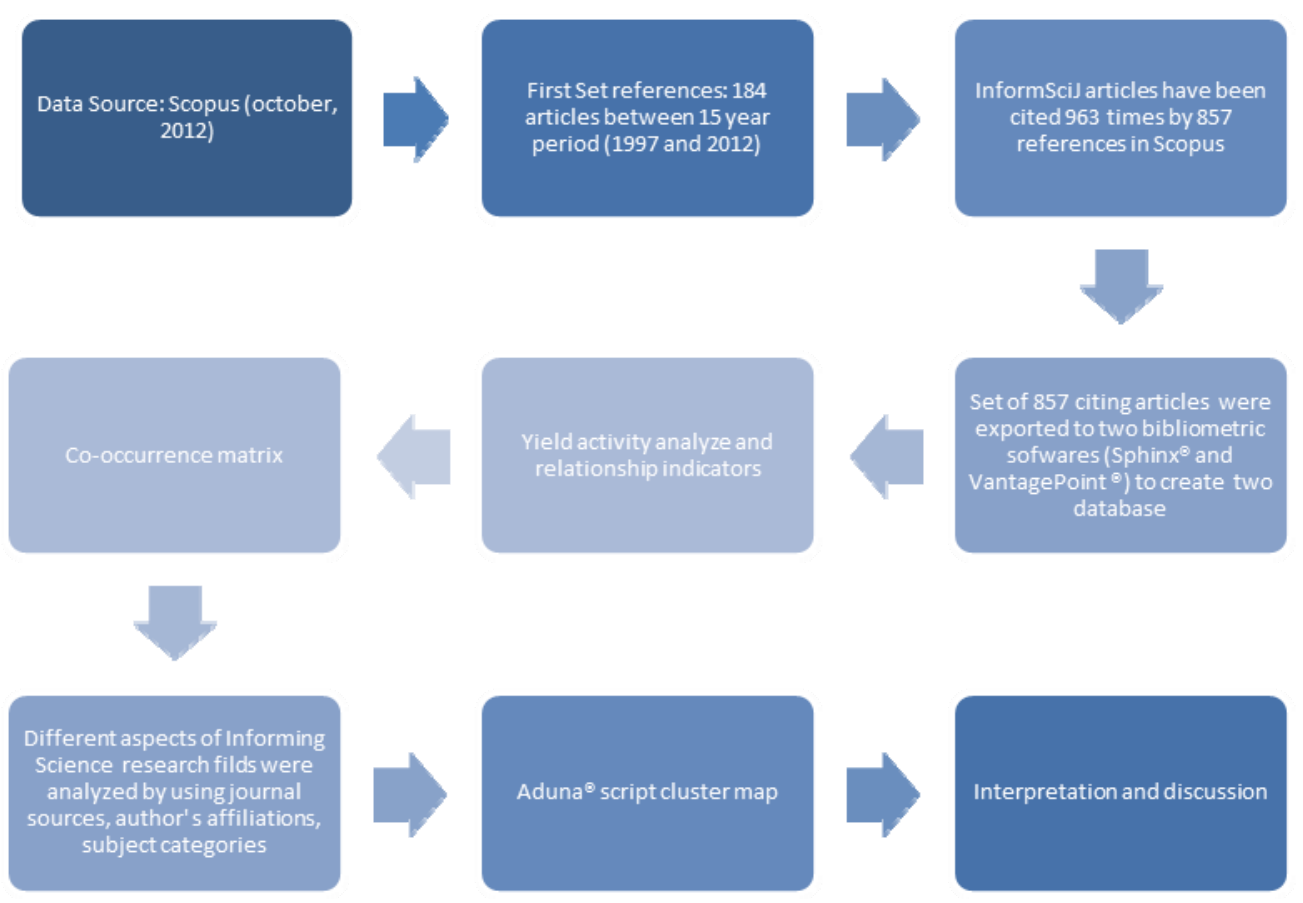

Figure 2: Study stages

\section{Results}

In this section, we put forward the results of the bibliometric analysis. We start with InformSciJ articles impact measures: h-index and articles citation impact ranking. In a second time we treat citing (or first generation citations) publications. The total number of citing papers in this part of the study is thus 857 . Let FGC denote this set.

\section{Impact Measures}

\section{InformSciJ articles impact measures}

Citation impact measures the recognition of published results through citations. The impact of each individual article can be compared by sorting them by cited article rank. In Scopus this is easily done by chosen "sort cited by". The paper with the greatest impact is at top of InformSciJ articles list.

The h-index quantifies the journal's number of articles that have received at least $\mathrm{h}$ citations. It is an indicator of both journal scientific productivity and scientific impact. In our case, if we consider the impact of 184 articles, 12 of them have been cited at least 12 times. As we see in Figure 3 , the $\mathrm{h}$ index is 12 . 


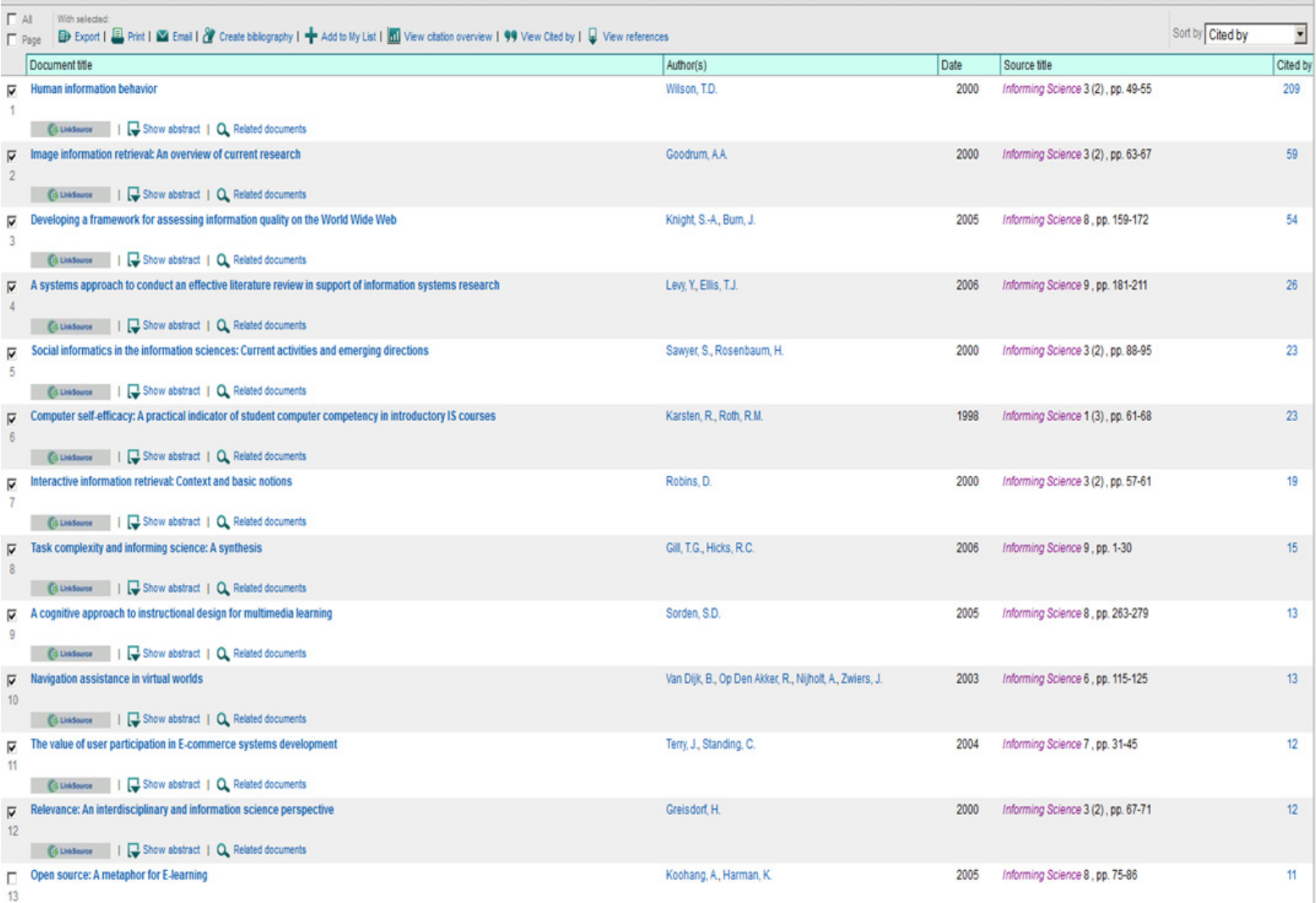

Figure 3: Screenshot of Scopus interface shows the data for the set of thirteen publications ranked by the number of times each publication has been cited

Table 1: The data for the set of top ten publications ranked by time cited

\begin{tabular}{|c|c|c|c|c|}
\hline Authors & Title & Year & Volume & Cited by \\
\hline Wilson, T.D. & Human information behavior & 2000 & 3 & 209 \\
\hline Goodrum, A.A. & $\begin{array}{l}\text { Image information retrieval: An overview of current } \\
\text { research }\end{array}$ & 2000 & 3 & 59 \\
\hline Knight, S.-A., Burn, J. & $\begin{array}{l}\text { Developing a framework for assessing information } \\
\text { quality on the World Wide Web }\end{array}$ & 2005 & 8 & 54 \\
\hline Levy, Y., Ellis, T.J. & $\begin{array}{l}\text { A systems approach to conduct an effective literature } \\
\text { review in support of information systems research }\end{array}$ & 2006 & 9 & 26 \\
\hline $\begin{array}{l}\text { Sawyer, S., Rosenbaum, } \\
\text { H. }\end{array}$ & $\begin{array}{l}\text { Social informatics in the information sciences: Current } \\
\text { activities and emerging directions }\end{array}$ & 2000 & 3 & 23 \\
\hline Karsten, R., Roth, R.M. & $\begin{array}{l}\text { Computer self-efficacy: A practical indicator of stu- } \\
\text { dent computer competency in introductory IS courses }\end{array}$ & 1998 & 1 & 23 \\
\hline Robins, D. & $\begin{array}{l}\text { Interactive information retrieval: Context and basic } \\
\text { notions }\end{array}$ & 2000 & 3 & 19 \\
\hline Gill, T.G., Hicks, R.C. & Task complexity and informing science: A synthesis & 2006 & 9 & 15 \\
\hline Sorden, S.D. & $\begin{array}{l}\text { A cognitive approach to instructional design for mul- } \\
\text { timedia learning }\end{array}$ & 2005 & 8 & 13 \\
\hline $\begin{array}{l}\text { Van Dijk, B., Op Den } \\
\text { Akker, R., Nijholt, A., } \\
\text { Zwiers, J. }\end{array}$ & Navigation assistance in virtual worlds & 2003 & 6 & 13 \\
\hline
\end{tabular}


Table 1 lists the ten articles that are the most cited. This list was compiled from all of the journal's publications during the period 1997 -2012, therefore it needs to be remembered that the older publications are more likely to have more citations than more recent publications.

\section{Citing articles or first generation citations to InformSciJ}

This part of our study will consider the FGC set of 857 citations to 184 InformSciJ articles published from its foundation in 1997 through 2012. For this set, 29 articles have been cited at least 29 times (the $h$ index is 29). The higher number of citations indicates a sustained level of relevance in our field of research. The ten most influential works are shown in Table 2.

Table 2: Top ten cited articles of FGC to InformSciJ articles

\begin{tabular}{|c|c|c|c|c|}
\hline Authors & Title & Year & Source title & Cited by \\
\hline Markus, M.L. & $\begin{array}{l}\text { Toward a theory of knowledge } \\
\text { reuse: Types of knowledge reuse } \\
\text { situations and factors in reuse suc- } \\
\text { cess }\end{array}$ & 2001 & $\begin{array}{l}\text { Journal of Management } \\
\text { Information Systems }\end{array}$ & 289 \\
\hline $\begin{array}{l}\text { Blei, D.M., Jor- } \\
\text { dan, M.I. }\end{array}$ & Modeling Annotated Data & 2003 & $\begin{array}{l}\text { SIGIR Forum (ACM Spe- } \\
\text { cial Interest Group on } \\
\text { Information Retrieval) }\end{array}$ & 209 \\
\hline $\begin{array}{l}\text { Kherfi, M.L., } \\
\text { Ziou, D., } \\
\text { Bernardi, A. }\end{array}$ & $\begin{array}{l}\text { Image retrieval from the World } \\
\text { Wide Web: Issues, techniques, and } \\
\text { systems }\end{array}$ & 2004 & ACM Computing Surveys & 126 \\
\hline Kling, R. & $\begin{array}{l}\text { Learning about information tech- } \\
\text { nologies and social change: The } \\
\text { contribution of social informatics }\end{array}$ & 2000 & Information Society & 115 \\
\hline Moody, D.L. & $\begin{array}{l}\text { Theoretical and practical issues in } \\
\text { evaluating the quality of conceptual } \\
\text { models: Current state and future } \\
\text { directions }\end{array}$ & 2005 & $\begin{array}{l}\text { Data and Knowledge En- } \\
\text { gineering }\end{array}$ & 103 \\
\hline $\begin{array}{l}\text { Pettigrew, K.E., } \\
\text { Fidel, R., Bruce, } \\
\text { H. }\end{array}$ & $\begin{array}{l}\text { Conceptual frameworks in infor- } \\
\text { mation behavior }\end{array}$ & 2000 & $\begin{array}{l}\text { Annual Review of Infor- } \\
\text { mation Science and Tech- } \\
\text { nology }\end{array}$ & 78 \\
\hline $\begin{array}{l}\text { Bilal, D., Kirby, } \\
\text { J. }\end{array}$ & $\begin{array}{l}\text { Differences and similarities in in- } \\
\text { formation seeking: Children and } \\
\text { adults as Web users }\end{array}$ & 2002 & $\begin{array}{l}\text { Information Processing } \\
\text { and Management }\end{array}$ & 77 \\
\hline $\begin{array}{l}\text { Fisher, K.E., } \\
\text { Durrance, J.C., } \\
\text { Hinton, M.B. }\end{array}$ & $\begin{array}{l}\text { Information grounds and the use of } \\
\text { need-based services by immigrants } \\
\text { in queens, New York: A context- } \\
\text { based, outcome evaluation ap- } \\
\text { proach }\end{array}$ & 2004 & $\begin{array}{l}\text { Journal of the American } \\
\text { Society for Information } \\
\text { Science and Technology }\end{array}$ & 63 \\
\hline Heinström, J. & $\begin{array}{l}\text { Five personality dimensions and } \\
\text { their influence on information be- } \\
\text { haviour }\end{array}$ & 2003 & Information Research & 58 \\
\hline $\begin{array}{l}\text { Widén-Wulff, } \\
\text { G., Ginman, M. }\end{array}$ & $\begin{array}{l}\text { Explaining knowledge sharing in } \\
\text { organizations through the dimen- } \\
\text { sions of social capital }\end{array}$ & 2004 & $\begin{array}{l}\text { Journal of Information } \\
\text { Science }\end{array}$ & 56 \\
\hline
\end{tabular}

Another metric indicator is the evolution of citations during the studied period. Figure 4, illustrates the impact trend for the dataset. This evolution of citations is in part the consequence of the window of time during which those articles have been available; the longer an article is available and the more are the chances to be cited. Nevertheless, Table 2 shows that the list of top ten articles ranked by citation counts does not follow an ascending chronological order. 


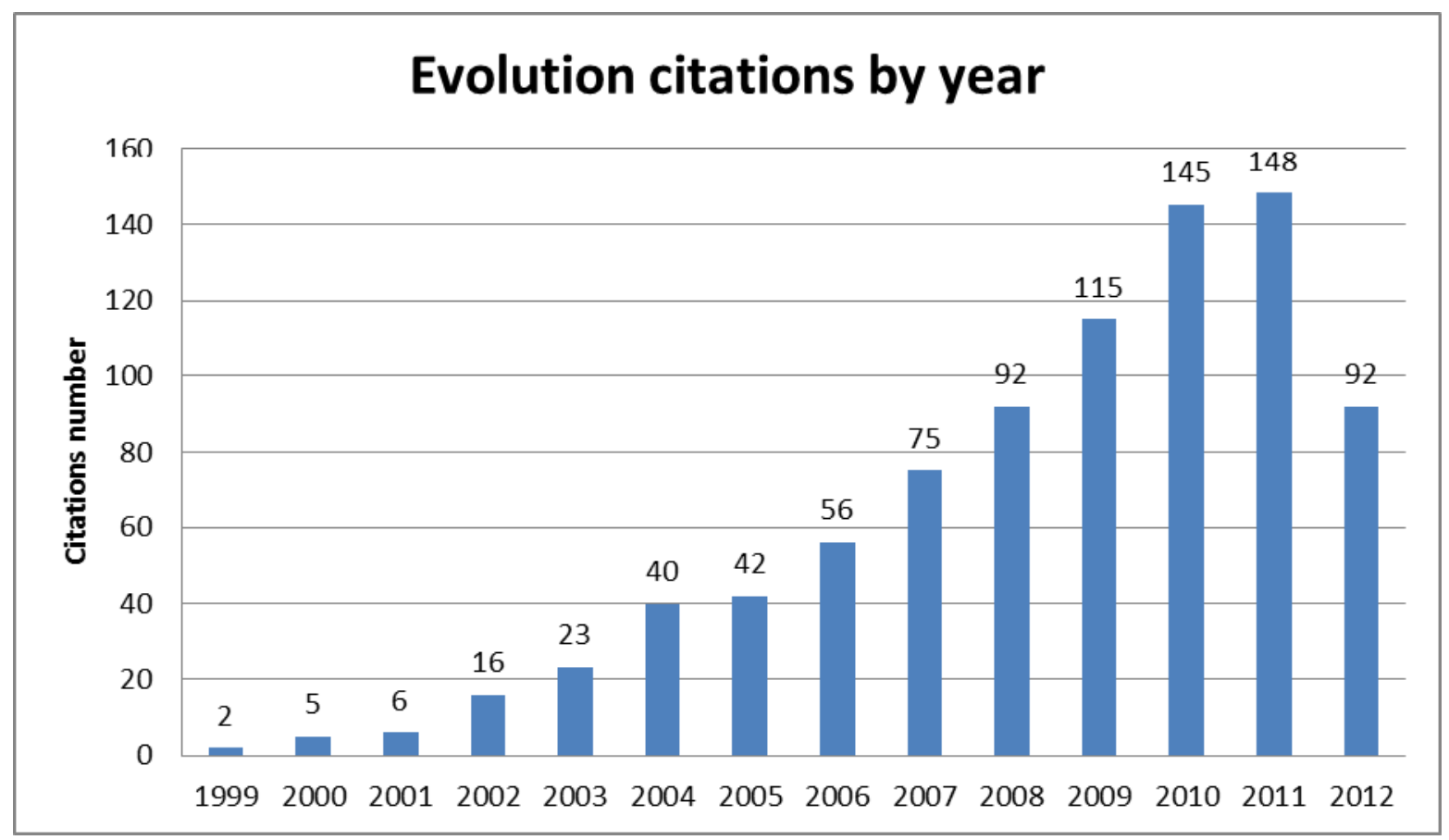

Figure 4: Distribution of citations between 1999 and 2012

From Figure 4 the citation evolution is exponential giving a mean value of about 70 citations during the last ten years.

\section{Document type, language, scholar source}

Other quantifiable indicators can be extracted from the FGC data set. These items are the documents type, the language of references, and the source (journals, proceedings, books, etc).

Concerning the document type of citations they are mainly articles, and conference papers as shown in Table 3.

Table 3: Distribution by document type

\begin{tabular}{|l|r|r|}
\hline Document type & Nb & \% cit. \\
\hline Article & 535 & $62,40 \%$ \\
\hline Conference Paper & 256 & $29,90 \%$ \\
\hline Editorial & 2 & $0,20 \%$ \\
\hline Letter & 1 & $0,10 \%$ \\
\hline Note & 1 & $0,10 \%$ \\
\hline Review & 62 & $7,20 \%$ \\
\hline Total & 857 & 1 \\
\hline
\end{tabular}

The documents' language is 95\% English, and the other 5\% is composed of 12 different languages: Portuguese, Persian, Spanish, German, Chinese, Croatian, Czech, Estonian, French, Japanese, Lithuanian, and Turkish. This is an indicator of the wide dissemination of InformSciJ publications in different countries, if English is seen as the international research language. Countries have journals for domestic users written in their own languages. 
The examination of FGC sources includes a criterion to find users' discipline origin. Articles were published in 160 different sources. According to the number of citations by source title it is possible to have an idea of the best ranked in terms of references number. Table 4 shows the top fifteen sources where articles from InformSciJ have been cited. Two titles published by the Informing Science Institute are also indicated.

Table 4: Top Ten FGC sources

\begin{tabular}{|l|l|}
\hline \multicolumn{1}{|c|}{ Source title } & $\begin{array}{c}\text { \# cita- } \\
\text { tions }\end{array}$ \\
\hline $\begin{array}{l}\text { Lecture Notes in Computer Science Including Subseries Lecture Notes in Artificial Intelligence and } \\
\text { Lecture Notes in Bioinformatics }\end{array}$ & 49 \\
\hline Informing Science & 48 \\
\hline Information Research & 41 \\
\hline Journal of the American Society for Information Science and Technology & 36 \\
\hline Information Processing and Management & 14 \\
\hline Proceedings of the ASIST Annual Meeting & 12 \\
\hline Proceedings of the Annual Hawaii International Conference on System Sciences & 11 \\
\hline ACM International Conference Proceeding Series & 10 \\
\hline Communications in Computer and Information Science & 10 \\
\hline Interdisciplinary Journal of Information Knowledge and Management & 9 \\
\hline Annual Review of Information Science and Technology & 9 \\
\hline Computers in Human Behavior & 9 \\
\hline Journal of Documentation & 9 \\
\hline Library and Information Science Research & 9 \\
\hline Ciencia Da Informacao & 7 \\
\hline
\end{tabular}

We observe from Table 4 that $28 \%$ of citations to InformSciJ are from papers published in this journal and from the Interdisciplinary Journal of Information Knowledge and Management, another IS Institute journal. Nevertheless the $72 \%$ of top ten articles come from other well-known journals and conferences proceedings.

\section{Exploring Data Extracted from Authors' Affiliation}

\section{Mapping the papers production according to countries}

VantagePoint allowed us to build-up a countries co-occurrence matrix. The matrix was used to visualize the international dimension of citations to InformSciJ publications. 


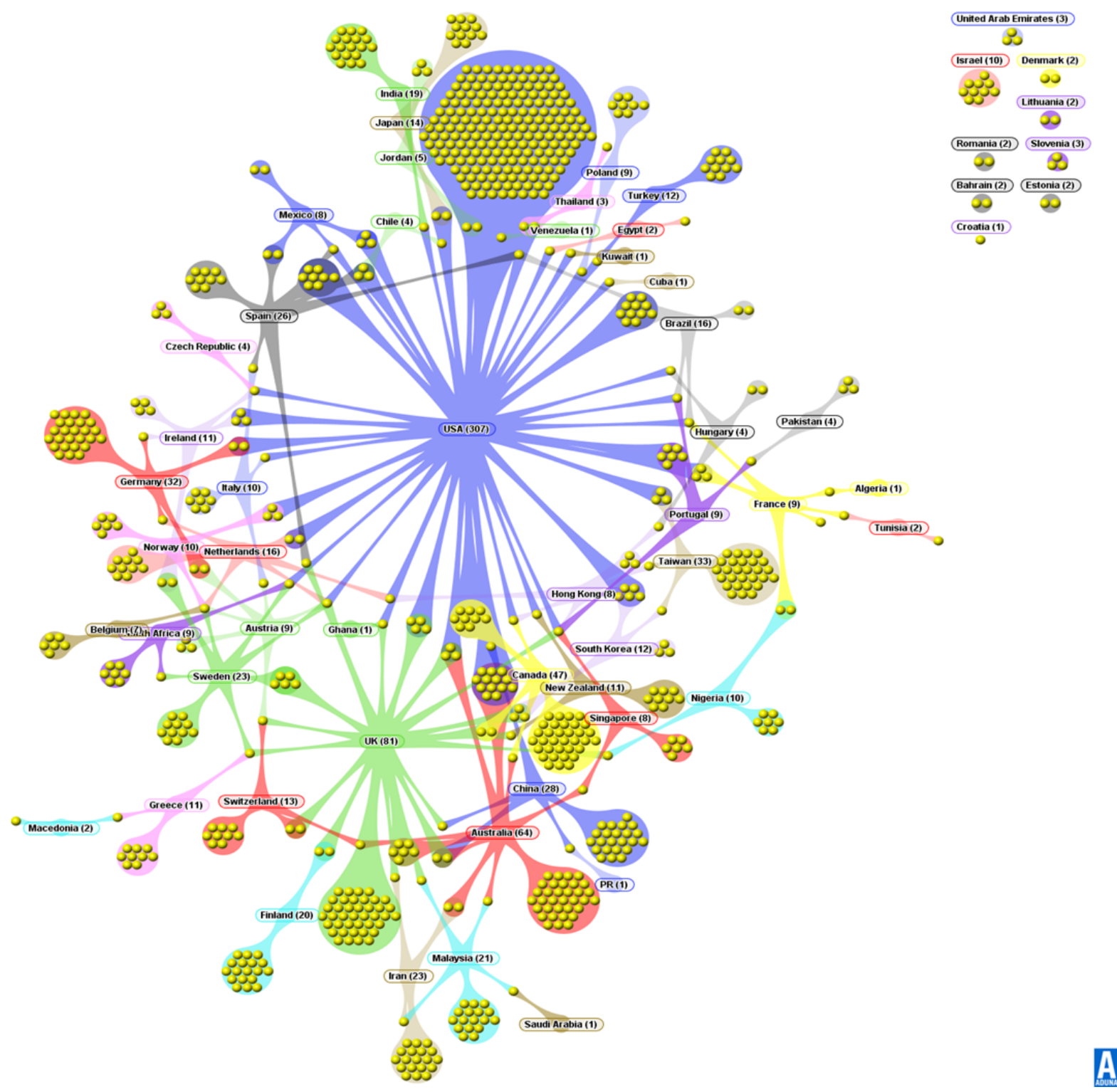

Figure 5: Paper production by countries

In Figure 5 each country has a different color and each dot represents one citation. The map shows the central position of United States and United Kingdoms.

There are 59 different countries in authors' affiliation addresses. The top 25 countries where authors cite the journal are USA, UK, Australia, Canada, Taiwan, Germany, China, Spain, Iran, Sweden, Malaysia, Finland, India, Brazil, Netherlands, Japan, Switzerland, South Korea, Turkey, Greece, Ireland, New Zealand, Israel, Italy, Nigeria, Norway, Austria, France, Poland, and Portugal.

\section{Subject Areas}

This analysis is made on the basis of Scopus subject categories.

Articles published in this journal are placed in only one subject area according to Scopus: Social Science. Nevertheless, FGC to this journal are published in multiple sources in different fields. Among them are Computer Science, Social Sciences, Engineering, Mathematics, Business, Man- 
agement and Accounting, Decision Sciences, Psychology, Biochemistry, Genetics and Molecular Biology, Medicine, and Arts and Humanities.

Though papers from Computer Science and Social Science are numerous 66\%, the other $44 \%$ comes from a broad-spectrum (20 subjects).

In fact, the FGC are spread in 22 subject categories; one journal can be in more than one category (Table 4)

Table 4: Subject categories

\begin{tabular}{|l|l|}
\hline \multicolumn{1}{|c|}{ Subject categories } & \# Citations \\
\hline Computer Science & 483 \\
\hline Social Sciences & 394 \\
\hline Engineering & 109 \\
\hline Mathematics & 75 \\
\hline Business, Management and Accounting & 70 \\
\hline Decision Sciences & 51 \\
\hline Psychology & 32 \\
\hline Biochemistry, Genetics and Molecular Biology & 31 \\
\hline Medicine & 27 \\
\hline Arts and Humanities & 16 \\
\hline Agricultural and Biological Sciences & 9 \\
\hline Economics, Econometrics and Finance & 7 \\
\hline Health Professions & 7 \\
\hline Materials Science & 7 \\
\hline Physics and Astronomy & 7 \\
\hline Earth and Planetary Sciences & 6 \\
\hline Environmental Science & 4 \\
\hline Multidisciplinary & 4 \\
\hline Nursing & 3 \\
\hline Chemical Engineering & 2 \\
\hline Neuroscience & 2 \\
\hline Energy & 1 \\
\hline
\end{tabular}

\section{Discussion and Conclusions}

In this bibliometric study, where publication data from Scopus were used, we have treated a set of first generation citations to InformSciJ. We recognized that there were limitations intrinsic to the data set. We analyzed the journal readership.

The findings presented in previous sections lead to the following conclusions:

- The impact trend of first generation citations has increased, as shown in Figure 4. The "hindex" of the FGC is 29 .

- The subject categories are varied up to 22 (Table 4), which demonstrate the high degree of transdisciplinarity of Informing Science, even if there is a concentration in Computer Science, Social Sciences, and Engineering with more the 100 references for each other. 
- Compiling the affiliation data reveals, as shown in Figure 5, the particular influence of United States and United Kingdom, but gives us one overview of the variety of countries where users come from.

We recognize, as does Murphy (2011), that authors and readers may use knowledge from variety of fields and that the journal is a "meeting ground between disciplines" (T. Grandon Gill, in Murphy, 2011). Nevertheless, there is a slight difference in international contribution trends: the second country in number of articles is United Kingdom and not Australia for our set.

This study confirms that after more than a decade the Informing Science philosophy continues to bring together researchers working in IS from many disciplines and nations. Moreover, IS as framework is encouraging the transdisciplinarity movement of science, research and practice.

\section{How is the Informing Science Transdiscipline Going to Move Forward?}

The survey by citation analysis is one of the ways helping to provide the answers to these questions. After InformSciJ others ISI journals have been added. It could also be useful to do a bibliometric study for those journals to have an overview of the transdiscipline's evolution.

But even at the current level aggregation, bibliometric should always be used as a complementary tool to other analytical approaches. As pointed out earlier, the present study has its own limitations because the bibliometric analysis was done with data indexed by only one commercial data base. Researchers should use these methods as a complement to traditional qualitative methods of reviewing literature.

We must remember that "Rigor, openness, and tolerance are the fundamental characteristics of the transdisciplinary attitude and vision. Rigor in argument, taking into account all existing data, is the best defense against possible distortions. Openness involves an acceptance of the unknown, the unexpected and the unforeseeable. Tolerance implies acknowledging the right to ideas and truths opposed to our own " ("Charter of transdisciplinarity," 1994).

\section{References}

Baneyx, A. (2008). "Publish or Perish" as citation metrics used to analyze scientific output in the humanities: International case studies in economics, geography, social sciences, philosophy, and history. Archivum Immunologiae et Therapiae Experimentalis, 56(6), 363-371. doi: 10.1007/s00005008-0043-0

Börner, K., Chen, C., \& Boyack, K. W. (2003). Visualizing knowledge domains. Annual Review of Information Science and Technology, 37(1), 179-255. doi: 10.1002/aris.1440370106

Charter of transdisciplinarity. (1994) Retrieved 01/27/2013, from http://cirettransdisciplinarity.org/chart.php\#fr

Choi, B. C. K., \& Pak, A. W. P. (2006). Multidisciplinarity, interdisciplinarity and transdisciplinarity in health, services, education and policy: 1 . Definitions, objectives, and evidence of effectiveness. Clinical \& Investigative Medicine, 29(6), 351-364.

Chubin, D. E., Porter, A. L., \& Rossini, F. A. (1984). "Citation classics" analysis: An approach to characterizing interdisciplinary research. Journal of the American Society for Information Science, 35(6), 360-368. doi: 10.1002/asi.4630350608

Cohen, E. B. (1999). Reconceptualizing information systems as a field of the discipline informing science. Journal of Computing and Information Technology, 3(7), 213-219. 
Cohen, E. B. (2009). A philosophy of Informing Science. Informing Science: the International Journal of an Emerging Transdiscipline, 12, 1-15. Retrieved from http://www.inform.nu/Articles/Vol12/ISJv12p001-015Cohen399.pdf

Flinterman, J. F., Teclemariam-Mesbah, R., Broerse, J. E. W., \& Bunders, J. F. G. (2001). Transdisciplinary: The new challenge for biomedical research. Social Science and Medicine, 21, 253.

Garfield, E. (1955). Citation indexes for science. A new dimension in documentation through association of ideas. Science, 122(3159), 1108-1111.

Garfield, E. (1997). Concept of citation indexing. Far Eastern State University. Retreived from http://www.garfield.library.upenn.edu/papers/vladivostok.html

Gazni, A., Sugimoto, C. R., \& Didegah, F. (2012). Mapping world scientific collaboration: Authors, institutions, and countries. Journal of the American Society for Information Science and Technology, 63(2), 323-335. doi: 10.1002/asi.21688

Gill, G. (2009). An open letter to the Informing Science Community. Informing Science: the International Journal of an Emerging Transdiscipline, 12, v-x. Retrieved from http://inform.nu/Articles/Vol12/ISJv12pv-xGill.pdf

Gill, G., \& Bhattacherjee, A. (2007). The Informing Sciences at a crossroads: The cole of the client. Informing Science: the International Journal of an Emerging Transdiscipline, 10, 17-39. Retrieved from http://www.inform.nu/Articles/Vol10/ISJv10p017-039Gill317.pdf

Gill, G., \& Cohen, E. B. (2009). Foundations of informing science: 1999-2008. Santa Rosa, CA: Informing Science Institute.

Glänzel, W. (2012). Data sources, cleaning \& journal impact mesures. ESSS European Summer School for Scientometrics (pp. 17-26): ESSS.

Gossman, D. G. (1979). A quantitative system for the assessment of initial organizational needs in transdisciplinary research. Degree Master of Science, Michigan State University. Retrieved from http://gossman.org/daveg/thchapt1.htm

Harzing, A. W. (2007). Publish or perish. Available from http://www.harzing.com/pop.htm

Jasco, P. (2009). Newswire analysis: Google Scholar's ghost authors, lost authors, and other problems Library Journal. Retrieved from http://www.libraryjournal.com/article/CA6698580.html

Meho, L. I., \& Yang, K. (2007). Impact of data sources on citation counts and rankings of LIS faculty: Web of Science versus Scopus and Google Scholar. Journal of the American Society for Information Science and Technology, 58(13), 2105-2125.

Murphy, W. (2011). The Informing Science Institute: The informing system of transdiscipline. Informing Science: the International Journal of an Emerging Transdiscipline, 14, 91-123. Retrieved from http://www.inform.nu/Articles/Vol14/ISJv14p091-123Murphy598.pdf

Nicolescu, B. (2002). Manifesto of transdisciplinarity (K.-C. Voss, Trans.). New York: State University of New York (SUNY) Press.

Osareh, F. (1996). Bibliometrics, citation analysis and co-citation analysis: A review of literature I. Libri, 46, 149-158).

Rosenfield, P. L. (1992). The potential of transdisciplinary research for sustaining and extending linkages between the health and social sciences. Social Science and Medicine, 35.

Sayama, H., \& Akaishi, J. (2012). Characterizing interdisciplinarity of researchers and research topics using web search engines. PLOS ONE, 7(6), e38747. doi:10.1371/journal.pone.0038747

Yang, K., \& Meho, L. I. (2006). Citation analysis: A comparison of Google Scholar, Scopus, and Web of Science. Proceedings of the American Society for Information Science and Technology, 43(1), 1-15. doi: $10.1002 /$ meet.14504301185 


\section{Biographies}

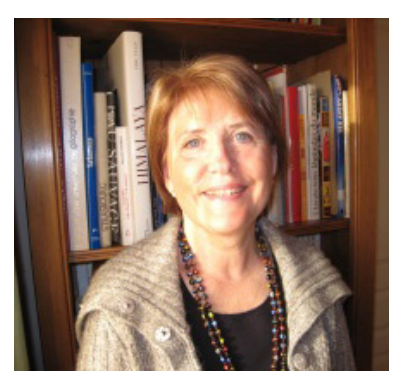

Amanda Regolini has 25 years of experience as information specialist. She is a research engineer at Irstea, where she has been responsible for the bibliometric analysis since 2006.

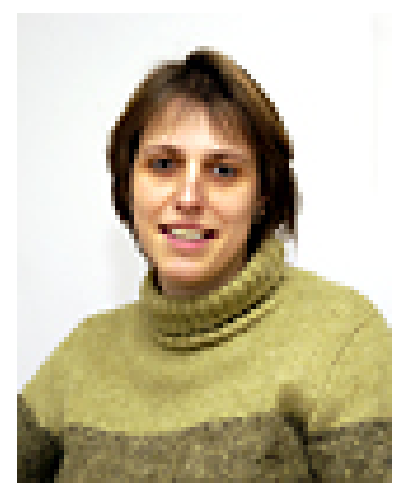

Emmanuelle Jannès-Ober is geographer and has more than 25 years of experience in managing scientific and technical information. She has worked for different international organizations in Africa and 10 years for the Institut Pasteur in Paris. Since 8 years, she is the head of the Scientific and Technical Information Department of Irstea. Since 3 years, she is also Deputy Director of the Direction of Foresight and Scientific Watch of Irstea. 